\title{
My Passion for Quality-of-Life and Well-Being Research: an Autobiography
}

\section{Joseph Sirgy ${ }^{1}$}

Received: 17 April 2015 /Accepted: 18 April 2015 /Published online: 28 April 2015 (C) Springer Science+Business Media Dordrecht and The International Society for Quality-of-Life Studies (ISQOLS) 2015

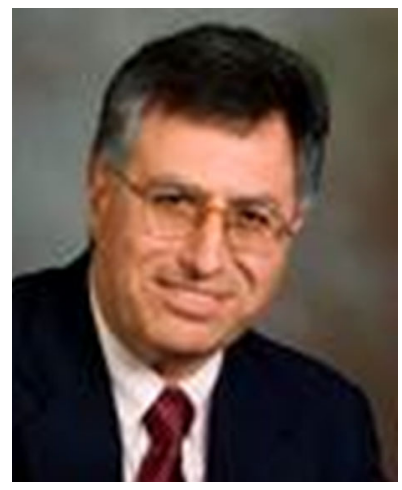

Before discussing my passion for quality-of-life (QOL) and well-being research, allow me to touch upon my educational/professional roots. I was born in 1952 in Cairo, Egypt of Lebanese/Syrian parents (my mother a Greek Orthodox, my dad a Greek Catholic). My early education was at St. George's College, an Irish parochial school in Cairo. At the age of 16 I left Egypt for Lebanon (Beirut) from where I immigrated to the USA. While wiating for my immigration papers to come through, I took on a job as a translator in a cinematography lab, where English, American, and French television shows were translated into Arabic subtitles. I arrived in the USA in 1970, afterwhich I started taking college evening courses at the community college in Los Angeles while

\section{Joseph Sirgy}

sirgy@vt.edu

1 Pamplin College of Business, Department of Marketing, Virginia Polytechnic Institute \& State University (Virginia Tech), 880 West Campus Drive (Office: 2025 Pamplin Hall), Blacksburg, VA 24061-0236, USA 
working odd jobs during the day. Several months later I was drafted in the U.S. Army. I served in military intelligence as an assistant interrogator/interpreter and was naturalized during my military tenure in 1972. During my military service I enrolled as a college student at Chaminade College in Hawaii, where I was able to complete my first 2 years of college. In 1973 I was discharged from the military and became a full-time college student at the University of California in Los Angeles (UCLA) where I majored in Psychology. I graduated from UCLA in 1974 afterwhich I became an employment interviewer/job analyst for the State of California Unemployment Department in Los Angeles. After a year on the job I joined the Masters Program in Experimental Psychology at California State University in Long Beach (CSULB). I graduated from CSULB in 1977 and joined the Doctoral Psychology Program at University of Massachusetts in Amherst (UMass). At UMass I was fortunate to customize my program of study in areas of psychology that I found most interesting, namely social/personality psychology, consumer psychology, and industrial/organizational psychology. I received my Ph.D. in 1979, afterwhich I joined the faculty ranks of the College of Business at Virginia Polytechnic Institute \& State University (Virginia Tech) as an Assistant Professor of Business Administration. I have been at Virginia Tech ever since. I was promoted to full professor in 1991; the professorship is supported by an endownment.

My passion for quality-of-life (QOL) research was sparked in the early 1980s when one of my doctoral students (H. Lee Meadow) completed his dissertation on elderly consumers. The goal of the dissertation was to develop a metric of consumer well-being focusing on the elderly shopping locally. The basic premise was that local shopping conditions do play a significant role in elderly's QOL. His dissertation was the spark that ignited my passion for QOL research. Ever since, much of my research and writing concentrated on consumer well-being, employee well-being, material well-being, and community well-being.

The consumer well-being (CWB) research program I developed over the years involved the development of a set of metrics to capture CWB in various sectors: healthcare, transportation, retailing, real estate, higher education, and hospitality/travel/tourism. As such, the research focused on establishing respective theories, models, and metrics of CWB and testing the nomological validity of the CWB constructs by relating them to antecedents and consequences as well as moderators and mediators. Similar programs of research were forged in relation to employee well-being, material well-being, and community well-being.

However, one of my significant achievements in QOL research was the development of a theory of life satisfaction, as captured in my two books, The Psychology of Quality of Life (Sirgy 2002, 2012). Much of the research I have conducted in relation to consumer, employee, material, and community well-being led me to believe that people strive to maintain an optimal level of life satisfaction - an adaptation level of sorts. Deviations from that adaptation level prompts the individual to restore homeostatic balance using a variety of behavioral strategies. I identified several sets of strategies which I grouped them in two categories: interdomain strategies (e.g., bottom-up spillover, horizontal spillover, top-down spillover, and compensation) and intradomain strategies (e.g., re-evaluation based on personal history, re-evaluation based on the selfconcept, re-evaluation based on social comparison, goal selection, goal implementation and attainment, and re-appraisal). One of the most important behavioral strategies used to optimize life satisfaction is balance-balance between role demand within and 
between life domains. This is essentially what I referred to as "an inter-/intra-domain strategy." I subsequently wrote an article on the balanced life, published in the Journal of Happiness Studies, which won the Best Paper Award. Martin Seligman, the father of positive psychology, long proposed that life satisfaction can be achieved by having a pleasant life, an engaged life, and a meaningful life. I encoutered by advocating the concept of the balanced life.

To scan through the numerous publications I had over the last 35 years or so, please visit my personal website (see contact information). Other more recent scholarly activities related to QOL and well-being research are also located on my personal website. My best to all QOL scholars and students alike.

\section{References}

Sirgy, M. J. (2002). The psychology of quality of life. Dordrecht: Kluwer Academic Publishers.

Sirgy, M. J. (2012). The psychology of quality of life: Hedonic well-being, life satisfaction, and eudaimonia. Dordrecht: Springer. 